\title{
Pengaruh Personality dan Gender Terhadap Wawasan Lingkungan
}

\author{
Riwan Laraga \\ Widyaiswara Ahli Madya Badan Kepegawaian Pendidikan Dan Pelatihan Daerah Provinsi \\ Gorontalo,Indonesia \\ Email: riwanlaraga@gmail.com
}

\begin{abstract}
Personality is the human nature that dynamic to respond and react and interact relatively stable with other people or the environment in accordance with the underlying dimensions of personality that is conscientiousness, agreeableness, neuroticism, openness, extraversion in order to achieve personal goals. Gender is equity in the opportunity to actively participate in social programs based on gender differences factor. This means that the gender variable divide students according to gender. The purpose of this research is to know students perspective to the environmental insights related to personality and gender. This research use method ex post facto research with ANAVA $2 x 2$ models. The instrument used in this study is a test. A view of students to the environment that are constructed in the human mind then reflected became the basis for interacting with the environment and action to the environment.. Male and female student have diversity of looking at the surrounding environment so that environmental insight of students who have a high personality better than the environment insight students have low personality
\end{abstract}

Keywords: Personality; Gender; Environmental; Student.

\begin{abstract}
Abstrak
Personaliti adalah sifat-sifat seseorang yg dinamis dalam merespon dan bereaksi serta berinteraksi yang relatif stabil dengan orang lain atau lingkungannya sesuai dengan dimensi yang mendasari kepribadian yaitu conscientiousness, agreeableness, neuroticism, openness, extraversion dalam rangka mencapai tujuan pribadi. Gender adalah kesetaraan dalam memperoleh kesempatan untuk berperan aktif dalam program sosial berdasarkan faktor perbedaan jenis kelamin. Hal ini berarti bahwa variabel gender membagi siswa menurut jenis kelamin. Penelitian ini bertujuan untuk mengetahui tetang cara pandang terhadap wawasan lingkungan yang berkaitan dengan personality dan gender. Penelitian ini menggunakan metode penelitian ex post facto dengan model ANAVA $2 \times 2$. Instrumen yang digunakan dalam penelitian ini adalah tes. Siswa pria maupun wanita memiliki keragaman dalam memandang lingkungan sekitarnya sehingga wawasan lingkungan siswa yang berpersonality tinggi lebih baik dari pada wawasan lingkungan berpersonality rendah dan wasawasan lingkungan pria lebih baik dari pada wanita.
\end{abstract}

Kata Kunci: Personaliti; Gender; Lingkungan; Siswa 


\section{PENDAHULUAN}

Wawasan lingkungan hidup memiliki arti sebagai tinjauan, pandangan, konsepsi atau cara pandang terhadap lingkungan hidup. Cara pandang terhadap lingkungan hidup mencakup satu kesatuan ruang dengan segala benda, daya, keadaan dan mahluk hidup termasuk manusia dan kepribadiannya yang mempengaruhi kelangsungan perikehidupan dan kesejahteraan manusia serta mahluk hidup lainnya.

Permasalahan yang dihadapi antara lain : masih banyak orang yang memiliki wawasan lingkungan yang kurang terhadap lingkungan, adanya pemahaman yang keliru terhadap lingkungan, belum optimalnya tingkat pendidikan dalam mempengaruhi wawasan seseorang terhadap lingkungan. Masih banyak yang kurang mematuhi peraturan lingkungan dan program lingkungan hidup sekolah yang belum optimal.

Istilah "Lingkungan" Mohamad K.Wali (2010:4) dapat didefinisikan sebagai hasil interaksi dari semua organisme hidup dan tak hidup, komponen atau faktor dalam ruang yang diberikan dan waktu tertentu, bekerja sama untuk mendukung, yang utama mendapatkan dan mempertahankan hidup. Untuk mengelola lingkungan dengan baik dan berkelanjutan, kita perlu pemahaman yang kuat dari banyak dasar dan terapan ilmu, termasuk biologi, ekologi, kimia, geologi, oseanografi, hidrologi, klimatologi, geografi, ekonomi, ilmu politik, statistik, dan matematika.

Tujuan penelitian adalah untuk menegetahui mengetahui perbedaan wawasan lingkungan orang yang memilki personality tinggi dan rendah dan perbedaan wawasan lingkungan pria dan wanita setra pengaruh interaksi antara personality dan gender terhadap wawasan lingkungan.

$$
\text { Menurut Roberts }
$$

lingkungan hidup terbagi menjadi tiga jenis yaitu: 1) lingkungan alam meliputi udara, air, tanah dan organisme yang berada di dalam kelompok tanaman atau hewan hidup, 2) lingkungan buatan (Built Environment) meliputi kawasan perkotaan dan pembangunan industri, dan 3) lingkungan sosial berkaitan dengan kebudayaan, hukum, ekonomi, musik dan lain-lain.

Terciptanya pandangan yang berwawasan lingkungan, Chiras (1991:462) mengemukakan bahwa : 1) menggunakan sumberdaya secara hemat dan melakukan konservasi, 2) menggunakan kembali dan mendaur ulang bahan-bahan bekas pakai, 3) sedapat mungkin menggunakan sumberdaya yang dapat di perbaharui, dan 4) mengendalikan kepadatan penduduk.

Kepribadian atau personality sebenarnya merupakan kumpulan beberapa ciri-ciri antara lain : bertanggung jawab, sopan, dan pendiam kita kadang-kadang menggambarkan orang-orang yang memiliki "kepribadian yang baik,"

Menurut Pervin, (1996:1), dalam Rhodewalt, Personality is the complex organization of cognitions, affects and behaviors that gives direction and pattrern (coherence) to the persons life personality consists of both structures and processes and refl ects both nature (genes) and nurture experience (Kepribadian adalah organisasi kognisi yang komplek mempengaruhi perilaku untuk memberikan arah dan pola kehidupan seseorang.... kepribadian terdiri dari struktur dan proses, baik alam (gen) maupun pengalaman).

Dilain pihak Colquitt, LePine dan Wesson (2009:293) dalam The Big Five 
Model kepribadian menjelaskan ada lima dimensi yang mendasari kepribadian manusia yaitu conscientiousness, agreeableness, neuroticism, openness, dan extraversion. Big Five Personality adalah suatu pendekatan yang digunakan dalam psikologi untuk melihat kepribadian manusia melalui trait yang tersusun dalam lima buah domain kepribadian yang telah dibentuk dengan menggunakan analisis faktor.

Menurut Steven L. McShane (2010:40) bahwa "Big Five" dimensi, yang diwakili oleh akronim diuraikan dan dijelaskan : 1) Connscientiousness atau Kesadaran ciri orang-orang yang berhatihati, diandalkan, dan disiplin diri. Beberapa ahli berpendapat bahwa dimensi ini juga termasuk kehendak untuk mencapai sesuatu. Seseorang dengan kesadaran yang rendah cenderung ceroboh, kurang teliti, lebih teratur, dan tidak bertanggung jawab, 2) Agreeableness atau keramahan. Dimensi ini meliputi ciri-ciri yang sopan, baik hati, empatik, dan peduli. Beberapa ahli lebih memilih label "ramah kepatuhan" untuk dimensi ini, dengan lawannya menjadi "ketidakpatuhan bermusuhan." Orang dengan rendah agreeableness cenderung tidak kooperatif, cepat marah, dan mudah tersinggung. 3) Neurotisme ciri orang dengan tingkat kecemasan tinggi, permusuhan, depresi, dan kesadaran diri. Sebaliknya, orang dengan rendah neurotisme (kestabilan emosi tinggi) yang siap, aman, dan tenang. 4) Openness atau keterbukaan terhadap pengalaman. Dimensi ini adalah yang paling kompleks dan memiliki sedikit, perjanjian antara ulama. Hal ini biasanya mengacu pada sejauh mana orang imajinatif, kreatif, penasaran, dan estetis sensitif. Mereka yang mencetak rendah pada dimensi ini cenderung lebih tahan terhadap perubahan, kurang terbuka untuk ide-ide baru, dan lebih konvensional dan tetap dalam cara mereka. 5) Ekstroversi ciri orang yang keluar, banyak bicara, bersosialisasi, dan tegas. Sebaliknya adalah introversi, yang mencirikan mereka yang pendiam, pemalu, dan berhati-hati. Ekstrovert mendapatkan energi dari luar yang dunia (orang-orang dan hal-hal di sekitar mereka), sedangkan introvert mendapatkan energi mereka dari dunia internal, seperti refleksi pribadi pada konsep dan ide-ide. Introvert tidak perlu memiliki keterampilan sosial. Sebaliknya, mereka lebih cenderung untuk mengarahkan minat mereka untuk ide-ide dari pada kegiatan sosial. Introvert merasa cukup nyaman berada sendirian, sedangkan ekstrovert tidak. Kelima dimensi kepribadian yang tidak independen satu sama lain. beberapa ahlimenunjukkan bahwa kesadaran, agreeableness, dan neurotisisme rendah (emosional tinggi).

Menurut Fautos-Sterling (2006:302) mendefinisikan seks dan gender dalam sosiologi menggunakan istilah seks dan gender untuk membedakan identitas seks biologis dari peran gender.. Seks mengacu biologis identitas, laki-laki atau perempuan. Untuk sosiolog, konsep lebih penting adalah gender yang harapan belajar sosial dan perilaku yang terkait dengan anggota masing-masing jenis kelamin.

\section{METODE PENELITIAN}

Penelitian ini menggunakan metode hubungan sebab-akibat yang dibentuk melalui apa yang disebut ex post facto desain $2 \times 2$, Dalam penelitian ini, tidak ada manipulasi variabel independen di laboratorium atau pengaturan di lapangan, tetapi subjek telah terkena stimulus. 
Tabel 1. Desain Penelitian

$\mathrm{Y}=$ Wawasan Lingkungan

\begin{tabular}{|c|c|c|c|}
\hline & \multicolumn{2}{|c|}{$\begin{array}{l}\text { Personality } \\
\text { (A) }\end{array}$} \\
\hline & & Tinggi & Rendah \\
\hline Simple effek & & $\left(A_{1}\right)$ & $\left(\mathrm{A}_{2}\right)$ \\
\hline \multirow{2}{*}{$\begin{array}{l}\text { Gender } \\
\text { (B) }\end{array}$} & $\begin{array}{l}\text { Pria } \\
\left(\mathrm{B}_{1}\right)\end{array}$ & $\mathrm{A}_{1} \mathrm{~B}_{1}$ & $\mathrm{~A}_{2} \mathrm{~B}_{1}$ \\
\hline & $\begin{array}{l}\text { Wanita } \\
\left(B_{2}\right)\end{array}$ & $\mathrm{A}_{1} \mathrm{~B}_{2}$ & $\mathrm{~A}_{2} \mathrm{~B}_{2}$ \\
\hline
\end{tabular}

Keterangan :

\begin{tabular}{|c|c|}
\hline A & Personality \\
\hline $\mathrm{A}_{1}$ & $\begin{array}{l}\text { Kelompok orang yang } \\
\text { memiliki } \\
\text { tinggi }\end{array}$ \\
\hline $\mathrm{A}_{2}$ & $\begin{array}{l}\text { Kelompok } \\
\text { memiliki } \\
\text { rendah }\end{array}$ \\
\hline $\mathrm{B}$ & : Gender \\
\hline $\mathrm{B}_{1}$ & : Kelompok pria \\
\hline $\mathrm{B}_{2}$ & : Kelompok wanita \\
\hline $\mathrm{A}_{1} \mathrm{~B}_{1}$ & $\begin{array}{l}\text { Kelompok orang yang } \\
\text { memiliki personality } \\
\text { tinggi dan } \\
\text { kelompok pria. }\end{array}$ \\
\hline$A_{1} B_{2}$ & $\begin{array}{l}\text { Kelompok orang yang } \\
\text { memiliki personality } \\
\text { tinggi dan } \\
\text { kelompok wanita, }\end{array}$ \\
\hline $\mathrm{A}_{2} \mathrm{~B}_{1}$ & $\begin{array}{l}\text { Kelompok orang yang } \\
\text { memiliki personality } \\
\text { rendah dan } \\
\text { kelompok pria. }\end{array}$ \\
\hline$A_{2} B_{2}$ & $\begin{array}{l}\text { Kelompok orang yang } \\
\text { memiliki personality } \\
\text { rendah dan } \\
\text { kelompok wanita. }\end{array}$ \\
\hline
\end{tabular}

Adapun variabel dalam penelitian adalah: (1) variabel bebas utama (main effect) adalah personality (A) yang dikategorikan pada dua kelompok yaitu personality tinggi (A1) dan personality rendah (A2), (2) Variabel bebas moderator (simple effect) adalah Gender equality (B) yang dikategorikan pada dua kelompok yaitu: Priat (B1) dan Wanita (B2).

\section{HASIL DAN PEMBASAN}

Hasil dari karakteristik deskriptif skor wawasan lingkungan dari beberapa responden, data hasil penelitian yang dideskripsikan meliputi data variabel: (1) Personality $\left(\mathrm{X}_{1}\right)$; (2) Gender $\left(\mathrm{X}_{2}\right)$; dan (3) Wawasan lingkungan (Y). Variabel penelitian ini terdiri atas variabel bebas utama (main effect) meliputi: personality dan variabel bebas moderator (simple effect) adalah gender. Berdasarkan permasalah dalam penelitian ini, maka deskripsi data yang disajikan dalam penelitian ini adalah data tentang wawasan lingkungan orang yang memiliki personality tinggi (A1), personality rendah (A2), pria (B1), wanita (B2), kelompok orang yang memiliki personality tinggi dan kelompok pria (A1B1), kelompok orang yang memiliki personality rendah dan kelompok pria (A2B1), kelompok orang yang memiliki personality rendah dan kelompok wanita (A2B2),kelompok orang yang memiliki personality tinggi dan 
kelompok wanita (A1B2. Berikut 2 tabel hasil data :

Tabel 2. Deskriptif Data Seluruh Kelompok Wawasan Lingkungan pada A1, A2, B1, dan B2

\begin{tabular}{lrrrr}
\hline \multicolumn{1}{c}{ Kelompok } & \multicolumn{1}{c}{ A1 } & \multicolumn{1}{c}{ A2 } & B2 \\
\hline Minimum & 90,00 & 83,00 & 83,00 & 90,00 \\
Maximum & 118,00 & 119,00 & 118,00 & 119,00 \\
Mean & 106,55 & 102,77 & 102,70 & 106,67 \\
Median & 107,00 & 102,50 & 102,50 & 106,50 \\
Modus & 111,00 & 104,00 & 112,00 & 111,00 \\
Rentang & 28 & 36 & 35 & 29 \\
Jumlah Kelas & 6 & 6 & 6 & 6 \\
Panjang Kelas & 4 & 6 & 6 & 5 \\
Jumlah Data & 30 & 30 & 30 & 30 \\
\hline
\end{tabular}

Sumber : Olaha Data Primer

Tabel 3. Rangkuman Statistik Dasar Setiap Kelompok

\begin{tabular}{lrrrr}
\hline \multicolumn{1}{c}{ Kelompok } & \multicolumn{1}{l}{ A1B1 } & \multicolumn{1}{l}{ A1B2 } & A2B1 & \\
\hline Minimum & 97,00 & 83,00 & 90,00 & 101,00 \\
Maximum & 118,00 & 104,00 & 111,00 & 119,00 \\
Mean & 109,60 & 103,60 & 95,80 & 109,73 \\
Median & 111,00 & 96,00 & 104,00 & 104,00 \\
Modus & 112,00 & 104,00 & 111,00 & 104,00 \\
Rentang & 21 & 21 & 21 & 18 \\
Jumlah Kelas & 4 & 4 & 4 & 5 \\
Panjang Kelas & 5 & 5 & 5 & 15 \\
Jumlah Data & 15 & 15 & 15 & \\
\hline Sumber : Olaha Data Primer & & & & \\
\end{tabular}




\section{Tabel 4. Statistik Uji tentang A, B dan A*B terhadap Wawasan Lingkungan Hasil Perhitungan ANAVA 2x2}

\begin{tabular}{|c|c|c|c|c|c|c|}
\hline \multirow{2}{*}{ Sumber Varians } & \multirow{2}{*}{ Df } & \multirow{2}{*}{ JK } & \multirow{2}{*}{ RJK } & \multirow{2}{*}{ F - Hit } & \multicolumn{2}{|c|}{ F-tabel } \\
\hline & & & & & $a=0.05$ & $a=0.01$ \\
\hline Antar kelompok & 3 & $1.946,450$ & 648,817 & & & \\
\hline Dalam & & & & $18,840 * *$ & 2,769 & 4,152 \\
\hline Kelompok & 56 & 1928,533 & 34,438 & & & \\
\hline Personality (A) & 1 & 220,417 & 220,417 & $6,400 * *$ & & \\
\hline Gender (B) & 1 & 236,017 & 236,017 & $6.383 * *$ & 4,004 & 7,058 \\
\hline (A) Interaksi (B) & 1 & $1.490,017$ & $1.490,017$ & $43,267 * *$ & & \\
\hline Jumlah & 59 & $3.874,98$ & & & & \\
\hline
\end{tabular}

Sumber : Olaha Data Primer

\section{Hipotesis Pertama}

Hipotesis statistik tersebut dirumuskan dalam pernyataan sebagai berikut: bahwa wawasan lingkungan orang yang memiliki personality tinggi lebih baik dari pada wawasan lingkung orang yang memiliki personality rendah. Pengujian hipotesis pertama dilakukan dengan menggunakan uji Anava dua arah. Kriteria yang ditentukan adalah: tolak Ho jika harga $F$ hitung lebih besar dari signifikan pada $\alpha=0,05$. Dengan menggunakan perhitungan di peroleh hasil uji. Berdasarkan hasil uji pada Tabel Anava tersebut, apabila $\alpha<$ sig., maka Ho ditolak, sebaliknya bila $\alpha \geq$ sig., maka Ho diterima. Hasil uji pada Tabel Anava tersebut, hasilnya menunjukkan bahwa Fhitung $=6,400>$ Ftabel $=4,00$ adalah sangat signifikan. Jadi kesimpulannya Ho ditolak. Hal tersebut memberikan bukti secara empirik bahwa hipotesis pertama dalam penelitian ini teruji secara sangat signifikan

\section{Hipotesis Kedua}

Hipotesis statistik, dirumukan dalam kalimat pernyataan sebagai berikut: bahwa wawasan lingkungan wanita lebih baik dari pada wawasan lingkungan pria. Pengujian hipotesis pertama dilakukan dengan menggunakan uji Anava Dua Arah. Dengan menggunakan perhitungan. Berdasarkan hasil uji pada Tabel Anava, Apabila $\alpha<$ sig., maka Ho ditolak, sebaliknya bila $\alpha \geq$ sig, maka Ho diterima. Ternyata hasil analisis menunjukkan bahwa $\mathrm{F}$ hitung $=6,853>\mathrm{F}$ tabel $=4,00$ adalah sangat signifikan. Jadi kesimpulannya Ho ditolak. Hal ini berarti bahwa wawasan lingkungan wanita lebih baik dari pada wawasan lingkungan pria. adalah signifikan. Hal tersebut memberikan bukti secara empirik bahwa hipotesis kedua dalam penelitian ini teruji sangat signifikan.

\section{Hipotesis Ketiga}

Hasil uji hipotesis ini diprediksi akan memberikan hasil yang signifikan maka pada kelompok orang yang memiliki personality tinggi wawasan lingkungan pria lebih baik dari pada wawasan 
lingkungan wanita. Ternyata hasil data yang dianalisis menunjukkan bahwa Qhitung 12,88 > Qtabel 3,86 Jadi kesimpulannya siqnifikan artinya wawasan lingkungan pria lebih baik dari pada wawasan lingkungan wanita pada personality tinggi.

\section{Hipotesis Keempat}

Hasil uji hipotesis ini diprediksi akan memberikan hasil yang signifikan maka pada kelompok orang yang memiliki personality rendah wawasan lingkungan wanita lebih baik dari pada wawasan lingkungan pria. Ternyata hasil data yang dianalisis menunjukkan bahwa Qhitung 6,502 > Qtabel 3,86 Jadi kesimpulannya wawasan lingkungan wanita lebih baik dari pada wawasan lingkungan pria pada personality rendah.

\section{Hipotesis Kelima}

Hipotesis statistik tersebut, dirumuskan dalam pernyataan sebagai berikut: Terdapat interkasi antara personality dengan gender terhadap wawasan lingkungan. Pengujian hipotesis kedua dilakukan dengan menggunakan uji Anava Dua Arah. Kriteria pengujian adalah: terima Ho jika harga $F$ hitung tidak signifikan pada $\alpha=0,05$. Berdasarkan hasil perhitungan dengan menggunakan perhitungan. Hasil uji pada Tabel Anava tersebut, Apabila $\alpha<$ sig., maka H1 diterima. Sebaliknya bila $\alpha \geq \operatorname{sig}$, maka Ho ditolak. Hasil perhitungan pada hipotesis ini menunjukkan bahwa $\mathrm{F}$ hitung 43,267 < F tabel 4,00 adalah sangat signifikan. Jadi kesimpulannya Ho ditolak. Dengan demikian, uji hipotesis kelima yang menyatakan bahwa terdapat pengaruh interaksi personality dan gender equality terhadap wawasan lingkungan adalah terbukti secara signifikan. Hasil uji ini memberikan bukti bahwa secara empirik hipotesis kelima yang menyatakan bahwa terdapat interaksi antara personality dan gender terhadap wawasan lingkungan terbukti.

Personality manusia sangat bervariasi, namun pada penelitian ini difokuskan pada personality, yaitu personality tinggi dan personality rendah. Dua personality tersebut telah diketahui memberikan pengaruh yang signifikan dalam membentuk wawasan lingkungan. Orang yang memiliki personality tinggi juga memiliki wawasan lingkungan yang lebih baik dibandingkan dengan orang yang memiliki personality rendah. Peran gender dalam mempengaruhi pengetahuan ilmiah dan kepedulian lingkungan telah lama ditelaah oleh sosiologist dan environmentalist. Dalam hasil penelitian ini diketahui bahwa wanita memiliki wawasan yang lebih baik dibandingkan dengan pria. Personality dan gender memberikan pengaruh secara independen terhadap wawasan lingkungan.

Meskipun telah dilakukan upaya maksimal, Penelitian ini tentunya memiliki keterbatasan terutama metode yang digunakan dalam penelitian ini adalah ex post facto dengan menggunakan disain faktorial $2 \times 2$. Tentunya, tidak menutup kemungkinan terdapat metode atau disain lain yang dapat memberikan penjelasan yang lebih komprehensif sesuai dengan kondisi dan substansi yang berkenaan dengan obyek penelitian.

\section{PENUTUP}

\section{Simpulan}

Kesimpulan yang dapat diperoleh dari penelitian ini adalah wawasan lingkungan orang yang memiliki personality tinggi lebih baik dari pada wawasan lingkungan orang yang memiliki personality rendah, maka demikian pula wawasan lingkingan pria lebih baik dari 
pada wawasan lingkungan wanita. Pada personality tinggi wawasan lingkungan pria lebih tinggi dari pada wawasan lingkungan wanita dan pada personality rendah wawasan lingkungan wanita lebih tinggi dari pada wawasan lingkungan pria.

\section{Saran}

Personaliti dan gender adalah dua hal yang dapat dipastikan memiliki kontribusi terhadap lingkungan. Dan kontribusi tersebut dapat direkayasa dengan melakukan itervensi yang tepat. Guna mendapatkan formula intervensi yang tepat maka disarankan pada kondisi personaliti yang yang tinggi maka, intervensi sebaikanya dilakukan pada perempuan sementara untuk kondisi personality yang rendah maka intervensi perlu dilakukan pada kalangan berjenis kelamin laki-laki.

\section{DAFTAR PUSTAKA}

Chiras.D.Daniel.1991. Environmental

Science : Action for a Sustainable Future California: The Benjamin/ Cumming. Publishing.

Colqouitt A.Jason, Jeffery A. Lepine, Michael J, Wesson. 2011. Organizational Behavior. New York: McGraw Hill Companies. Enger.D.Eldon, Smith.F.Bradley. 2008. Environmental Science A Study of Interrelationshlps. New York: The McGraw-Hill

K.Wali Mohamad, Evrendilek Fatih, Fennessy.M,Siobhan. 2009. The Environment Science, Issues, and Solutions, Francis : nd the CRC Press

Maslow H Abraham.2000. Motivation and Personality. New York : Library of Conccres Grand

McShane L Steven, Mary Ann Von Glinow. 2010 . Organizational Behavior Emerging Knowledge and
Practice For The Real World. New

York:The McGraw-Hill

Roberts.D and Roberts.M.T.1994.
Planning and Ecology London:
Chapma

